International Journal of Economics, Business and Accounting Research (IJEBAR)

Peer Reviewed - International Journal

Vol-3, IsSue-4, 2019 (IJEBAR)

E-ISSN: 2614-1280 P-ISSN 2622-4771

https://jurnal.stie-aas.ac.id/index.php/IJEBAR

\title{
THE EFFECT OF TRILOGY LEADERSHIP STYLE ON INNOVATION PERFORMANCE THROUGH DYNAMIC AMBIDEXTERITY CAPABILITY (DAC) MEDIATION \\ (Study at the Youth Educational Center (YEC) Tutoring Institute)
}

\author{
Tomi Agus Triono ${ }^{1)}$ Ignatius Soni Kurniawan ${ }^{2)}$ \\ Alumni of the Economics Faculty Sarjanawiyata Tamansiswa \\ Email: Tomiagustriono87@gmail.com
}

\begin{abstract}
Abstrack: This study aims to test whether dynamic ambidexterity capability mediates the relationship between trilogy leadership style and performance innovation. The study took samples in the business organization of a Youth Educational Center (YEC) tutoring institution located in the Wirobrajan area of Yogyakarta. The results showed that each component of the trilogy leadership style affected the dynamic ambidexterity capability variable and the performance innovations of its members. . The findings show that the trilogy leadership style can affect performance innovation directly or through mediating dynamic ambidexterity capability. This confirms that the dynamic ambidexterity capability is able to mediate the influence between the trilogy leadership style on innovation performance.
\end{abstract}

Kata kunci : Ambidexterity, Leadership, Innovation

\section{Introduction}

The development of the business world causes changes very quickly and causes companies or organizations to keep moving and flexible in adapting to the environment (Sari 2017). The most important influence is the development of technology that is happening now that is increasingly creative and innovative (Prabawa et al, 2015).

Given that organizations today face a dynamic environment characterized by rapid technological change, innovation becomes important and becomes an essential factor in the success and competitive advantage of organizations (Press 2016). Creativity in organizations can be defined as the process by which new ideas that enable innovation are developed (Dama and Ogi 2018). The increasing importance of creativity as a driver of innovation and innovation success forces organizations to create work environments that support creative and innovative thinking (Nurjanah 2015).

Creating performance innovations requires the ability to explore new opportunities and exploit existing resources (Kristinawati and Tjakraatmadja 2017). Exploration is needed to see new opportunities and can be managed by companies to improve performance innovation (Kusumastuti, Safitri et al. 2016), as well as exploration is needed to explore existing resources to be further enhanced in building innovation performance within a company .

The challenge for companies is how to carry out activities simultaneously both exploration and exploitation to develop performance innovations so that they can compete in the long run (Popadić, Černe et al. 2015). An important factor influencing employee creativity is leadership to be a catalyst for creating and managing environments, work processes, organizational culture, 
International Journal of Economics, Business and Accounting Research (IJEBAR)

Peer Reviewed - International Journal

Vol-3, Issue-4, 2019 (IJEBAR)

E-ISSN: 2614-1280 P-ISSN 2622-4771

https://jurnal.stie-aas.ac.id/index.php/IJEBAR

and strategies that take care and maintain creativity, innovation, and success in organizations and leaders can do that both directly and indirectly ( Rahmawati 2019).

Good leadership towards his subordinates is to provide the widest possible space for them to increase their potential, then express them in creative ways and responsibilities in accordance with the abilities of each member (Musyafa 2015). The substance of the leadership style that is often researched today apparently is in the concept of trilogy leadership, this leadership style is a leadership style initiated by Ki Hadjar Dewantara that can encourage the performance of its members (Prayekti 2018).

Likewise in a tutoring institution that is a Youth Educational Center (YEC) tutoring agency, YEC Bimbel Institute of Education is one of the tutors in Yogyakarta. The continuity of an organization to continue to grow and be competitive is influenced by several aspects including the leader to achieve mutual praise. In an organization of course a leader is needed, the leadership style taught by Ki Hadjar Dewantara certainly can represent the leadership style used in the YEC lessons. So hopefully the leadership trilogy can affect the organization.

\section{Theorical Review}

\section{Leadership Trilogy}

Leadership itself can be interpreted as a process of influencing and directing employees or members in carrying out work that has been assigned to their members (Situmorang 2014). Leadership is an important aspect for a leader, because a leader must have a role as a group organizer to achieve the goals set. Leadership bias is defined as a process to direct and influence activities related to the assignment of company members in order to achieve goals (Kamalia 2016). Good leadership for its members is to provide the widest possible space for them to increase their potential, this is relevant to the leadership trilogy applied at Tamansiswa colleges (Musyafa 2015).

The trilogy of leadership which was extracted from the nation's own culture which has subtle values and character, even this has become an indicator of the leadership of the trilogy (Suparti 2013), namely: "Ing Ngarsa Sung Tuladha" literally Ing Ngarsa Sung Tulodha means that a leader is at the front and should set an example for its members. "Ing Madya Mangun Karsa" a leader must be able to provide motivation or arouse enthusiasm in the midst of its members in order to achieve common goals. "Tut Wuri Handayani" a leader must provide the freedom of its members with the full attention of its members from behind (Nugroho 2018).

\section{Performance Innovation}

The word innovation contains not the same meaning. Classically, innovation is defined as the process of making improvements by introducing a new in a new way, is a new idea, method or thinking, success utilizes a new idea, changes to dynamic thinking that comes from performance, and is a creative idea that is realized (Suryana and Bayu 2012).

Innovation is defined as a general understanding of new thinking or new methods and is also interpreted as an embodiment, combination, or sitensis of original knowledge, relevant, new values of products, ways, or services (Cropley 2009). In essence, innovation is something that has just been produced or as a process of adoption or application of something new by an organization in such a way that this organization becomes more competitive (Awaluddin 2014). 
International Journal of Economics, Business and Accounting Research (IJEBAR)

Peer Reviewed - International Journal

Vol-3, Issue-4, 2019 (IJEBAR)

E-ISSN: 2614-1280 P-ISSN 2622-4771

https://jurnal.stie-aas.ac.id/index.php/IJEBAR

According to (Sumiyarto 2006 in Awaluddin 2014) innovation is driven by: increasing market demands, increasing competition, changing technology. Sumiyarto said that innovation occurs faster when organizations form network structures with other organizations.

\section{Dyinamic Ambidexterity}

Ambidexterity is the ability at the same time to exploit existing resources and to explore new opportunities (Adler and Heckscher 2013). Exploitation focuses on perfecting and reusing both products and processes with available resources. Whereas Exploration emphasizes the organization and its managers on freedom and radical thinking that opens up big changes to the organization or what is called radical innovation (O'Reilly III and Tushman 2013).

\section{Metodologi Penelitian}

This research is quantitative descriptive, that is, research by describing or describing collected data in the form of numbers.

\section{Population and Sample}

The population in this study are employees who work as instructors at YEC Bimbel and the sample used is all teachers in YEC tutoring totaling 40 people, the technique used in this sample is a saturated sample technique in which all populations are used as samples because the total population is less than 100 people (Supriyanto and Machfudz 2010)

\section{Analisa Data}

Data analys is useing linear regression analysis and path analysis.

\section{Result and Discussion Instrument Quality Test}

The study will use item validity by testing the correlation between the total score of answers to questions. The results of the validity test using product moment correlation show that 12 questions on the leadership variable, 8 questions on the dynamic ambidexterity capability (DAC), 9 questions on the performance innovation variable have a significance value of less than $5 \%$ and a calculated value greater than 0.312 (rtable for $\mathrm{n}=40$ and $\alpha=5 \%$ ). All variable items are valid.

The reliability test results for the three research variables using alpha cronbach, showed that all research variables had alpha cronbach greater than 0.6 . The three research variables, namely trilogy leadership, DAC and performance innovation can be said to be reliable. The results of this validity test are to get valid questions from a number of questions that have been given first to the respondents, the number of valid questions then tested again by the reliability method (Umar 2004). 
International Journal of Economics, Business and Accounting Research (IJEBAR)

Peer Reviewed - International Journal

Vol-3, Issue-4, 2019 (IJEBAR)

E-ISSN: 2614-1280 P-ISSN 2622-4771

https://jurnal.stie-aas.ac.id/index.php/IJEBAR

Analisa Regresi Linier

Table 1 Linear regression

\begin{tabular}{ccc}
\hline Uji & Sig. & $\mathbf{t}_{\text {hitung }}$ \\
\hline $\begin{array}{c}\text { Kepmimpinan terhadap } \\
\text { DAC }\end{array}$ & 0,006 & 2.931 \\
\hline DAC terhadap Inovasi & 0.001 & 3.634 \\
\hline $\begin{array}{c}\text { Kepimpinan terhadap } \\
\text { Inovasi }\end{array}$ & 0.000 & 6.237 \\
\hline $\begin{array}{l}\text { Source: Primary data processed, 2019 } \\
\end{array}$
\end{tabular}

Analysis of the influence in this study uses regression. The regression used in this study is linear regression. The results of the leadership test of dynamic ambidexterity capability (DAC) of 0.006 ( $p<0.05$ ) and tcount of 2931 or bias can be said to be positive so that it can be said that there is a significant influence between the two variables. The results of the linear regression analysis of the effect of dynamic ambidexterity capability (DAC) on innovation performance of 0.001 ( $p$ $<0.05$ ) and tcount of 3.634 (positive) can be said to have a significant influence between the two variables. Likewise, the linear regression analysis test of the influence between trilogy leadership style on performance innovation has a P-value of 0,000 that value is smaller than the sig level of $5 \%(0.05)$ and has a tcount of 6,237 (positive) so that it can be said that there is a significant influence on these variables.

\section{Discussion}

1. The Effect of Leadership Style on Dynamic ambidexterity capability

The statistical results of the $t$ test of simple linear regression analysis on the leadership style variable has a positive influence of 0.429 , and the results of the $t$ value of 2.931 and a significance value of $0.006<0.05$. So the first hypothesis $(\mathrm{H} 1)$ which states that "The leadership style has a positive and significant effect on Dynamic ambidexterity capability" can be accepted. In accordance with the results of research conducted by (Nemanich and Vera 2009) there are findings that the transformational leadership style has a positive effect on Ambidexterity, therefore this study is in accordance with the first hypothesis where "trilogy leadership influences dynamic ambidexterity". Improved leadership will certainly have a positive impact on its members, where trilogy leaders who have the nature of supporting, motivating, and encouraging, will certainly be more influential members in doing work.

2. The Effect of Leadership Style on Performance Innovation

The results of the $t$ test statistic of simple linear regression analysis on the dynamic ambidexterity capability variable have a positive effect of 0.618 , and the results of the $t$ value of 6.237 and a significance value of $0.000<0.05$. So the second hypothesis $(\mathrm{H} 2)$ which states that "leadership style has a positive and significant effect on performance innovation" is declared acceptable. Previous literature conducted by research (Uslu, Bülbül et al. 2015) there is a psychitive relationship between transformational leadership styles that influence innovation organizations, this is in line with the hypothesis of this study so that this research can support my hypothesis about the trilogy leadership style that affects performance 
International Journal of Economics, Business and Accounting Research (IJEBAR)

Peer Reviewed - International Journal

Vol-3, Issue-4, 2019 (IJEBAR)

E-ISSN: 2614-1280 P-ISSN 2622-4771

https://jurnal.stie-aas.ac.id/index.php/IJEBAR

innovation. This hypothesis can be strengthened by the results of research from (Masambe, Soegoto et al. 2015) that in his research for leadership style variables the regression coefficient is positive, this can be interpreted if the leadership style is getting better, then employee performance will increase. In research conducted by (Mardiana 2017) there is also the result of research showing that the two variables, namely democratic leadership style and employee performance, have a positive influence.

3. Effects of Dynamic Ambidexterity capability on performance innovation.

The results of the $t$ test statistics of simple linear regression analysis on the Dynamic ambidexterity capability variable have a positive influence of 0.360 , and the results of the $t$ value of 3.634 and a significance value of $0.001<0.05$. So the third hypothesis (H3) which states that "Dynamic ambidexterity capability has a direction that has a positive and significant effect on performance innovation" is declared acceptable. The research conducted by (Kusumastuti, Kasim et al. 2018) also supports this third hypothesis and can become a research literature. In this research there are significant results between exploration and exploitation with innovation, which in ambidexterity there are major components namely exploration and exploitation. Therefore this study is in accordance with this hypothesis about Dynamic ambidexterity capability affect performance innovation. Research conducted by (Wang and Rafiq 2014) can strengthen the hypothesis that the authors propose because in his research found the results of a significant relationship between ambidextrous organizational culture, contextual ambidexterity and the results of new product innovations; Contextual ambidexterity mediates the relationship between ambidextrous organizational culture and the results of new product innovations. So that the ambidexterity ability of the members in an organization if it is developed can affect the performance innovation.Pengaruh Gaya Kepmimpinan Terhadap Inovsdi Konerja melalui mediasi dynamic ambidexterity capability.

The statistical results of the path test (path analysis) and friend bell test to determine the effect of mediation on mediating variables dynamic ambidexterity capability that mediates between leadership style variables and performance innovation variables can be said there is a mediating effect and can be proved by the results of the manual sobel test manually where the results of the account are greater than the table that is equal to $2.238>2.0243$. this shows that Dynamic ambidexterity capability is able to mediate the relationship between the influence of leadership style on innovation performance.

The above literature certainly can also support this fourth hypothesis, which is about the leadership style that Affects innovation performance and is mediated by Dynamic ambitxterity capability. This is because it is supported by several research results that can support previous hypotheses. So I believe the fourth hypothesis in this study can be proven. In the previous explanation, it has been explained the effect of each variable on the performance innovation innovation, which has stated there is an influence on each variable so that in this hypothesis if the leadership style is getting better and can see the ability

\section{Conclusion}

Based on the analysis and discussion of the research results, it can be concluded several things: (1) The leadership style of the YEC Bimbel institution is generally perceived as having a good 
International Journal of Economics, Business and Accounting Research (IJEBAR)

Peer Reviewed - International Journal

Vol-3, Issue-4, 2019 (IJEBAR)

E-ISSN: 2614-1280 P-ISSN 2622-4771

https://jurnal.stie-aas.ac.id/index.php/IJEBAR

and supportive attitude. This can be seen from all indicators of leadership style where researchers here use the trilogy leadership style as a variable that supports and runs well, this is reinforced by the results of data processing, which shows that the leadership style can affect innovation performance directly or indirectly.

(2) The performance of employees or teachers at YEC Bimbel in general tends to have good performance. With the support of leaders to always develop and always innovate in teaching their students. This is indicated by the indicators of performance innovations in which all indicators contribute high. Of course this is supported by the results of data analysis that employee performance innovation variables must be influenced by leadership style directly or through mediation Dynamic ambidexterity capability.

(3) The analysis result shows that the independent variable, namely leadership style, can directly influence performance innovation or can be mediated through Dynamic ambidexterity capability. If the leader is getting better at applying the trilogy leadership style within an organization or company and is capable see the capabilities possessed by its members can also have a good influence on the performance of its members.

\section{Suggestion}

Based on the results of research, discussion and conclusions above, the writer gives suggestions for the company should have a good leadership style to establish a good strategy to stay afloat and have a competitive advantage. More attention to the members of the company itself, especially Bimbe YEC for the teachers so that they can apply work innovations properly so as to provide satisfying teaching quality to their students For further authors to develop and expand research in order to obtain even more complete information about things that affect the leadership style to support the performance of its members.

\section{References}

Adler, P. And C. Heckscher (2013). "The Collaborative, Ambidextrous Enterprise/La Empresa Colaborativa Y Ambidiestra." Universia Business Review(40): 34.

Awaluddin, M. (2014). "Kajian Faktor Penentu Kinerja Usaha Kecil Di Kota Makassar." Jurnal Minds: Manajemen Ide Dan Inspirasi 2(2): 120-136.

Cropley, D. H. (2009). "Fostering And Measuring Creativity And Innovation: Individuals, Organisations And Products." Villalba, E.(Sud.). Measuring Creativity. Luxembourg: OPOCE: 257-279.

Dama, J. And I. W. Ogi (2018). "Pengaruh Inovasi Terhadap Dan Kreativitas Terhadap Kinerja Karyawan Pada Pt Bank Mandiri (Persero) Tbk. Manado." Jurnal EMBA: Jurnal Riset Ekonomi, Manajemen, Bisnis Dan Akuntansi 6(1).

Kamalia, F. (2016). Model Kepemimpinan Manajer BMT An-Nawawi Purworejo Dalam Meningkatkan Kinerja BMT, UIN Walisongo. 
International Journal of Economics, Business and Accounting Research (IJEBAR)

Peer Reviewed - International Journal

Vol-3, Issue-4, 2019 (IJEBAR)

E-ISSN: 2614-1280 P-ISSN 2622-4771

https://jurnal.stie-aas.ac.id/index.php/IJEBAR

Kristinawati, D. And J. H. Tjakraatmadja (2017). "Studi Konseptual Eksploratif Mengenai Hubungan Kapabilitas Dinamis Dengan Kinerja Perusahaan." Jurnal Manajemen Indonesia 17(1): 1-12.

Kusumastuti, R., Et Al. (2018). "Strategic Ambidexterity Learning Of Innovation Activities: A Study Of Indonesian Business Group Leader." Policy \& Governance Review 2(1): 70-84.

Kusumastuti, R., Et Al. (2016). "Developing Innovation Capability Of SME Through Contextual Ambidexterity." Bisnis \& Birokrasi Journal 22(1): 51-59.

Mardiana, M. (2017). "Pengaruh Gaya Kepemimpinan Demokratis Terhadap Kinerja Pegawai Pada Kantor Sekretariat Daerah Kota Samarinda." JURNAL UNIVERSITAS MULAWARMAN 2(1): 1802-1816.

Masambe, F., Et Al. (2015). "Pengaruh Gaya Kepemimpinan, Budaya Organisasi Dan Inovasi Pemimpin Terhadap Kinerja Karyawan Daihatsu Kharisma Manado." Jurnal EMBA: Jurnal Riset Ekonomi, Manajemen, Bisnis Dan Akuntansi 3(3).

Musyafa, H. (2015). Sang Guru: Novel Biografi Ki Hadjar Dewantara, Kehidupan, Pemikiran, Dan Perjuangan Pendiri Tamansiswa (1889-1959), Imania.

Nemanich, L. A. And D. Vera (2009). "Transformational Leadership And Ambidexterity In The Context Of An Acquisition." The Leadership Quarterly 20(1): 19-33.

Nugroho, A. S. (2018). "Pengaruh Gaya Kepemimpinan Transformasional Dan Komitmen Organisasi Terhadap Kinerja Karyawan Dengan Kepuasan Kerja Karyawan Sebagai Variabel Intervening (Studi Pada Karyawan PT. PLN (Persero) Distribusi Lampung Area Metro)." Program Pascasarjana Magister Manajemen Fakultas Ekonomi Dan Bisnis Universitas Lampung Bandar Lampung. STAI Darussalam Nganjuk ISSN: 2654-8186.

Nurjanah, S. (2015). Peranan Manajemen Inovasi Dalam Meningkatkan Kinerja Organisasi Pendidikan. Conference In Business, Accounting, And Management (CBAM).

O'Reilly III, C. A. And M. L. Tushman (2013). "Organizational Ambidexterity: Past, Present, And Future." Academy Of Management Perspectives 27(4): 324-338.

Popadić, M., Et Al. (2015). "Organizational Ambidexterity, Exploration, Exploitation And Firms Innovation Performance." Organizacija 48(2): 112-119.

Prayekti, P. (2018). "Peran Gaya Kepemimpinan Trilogi Dalam Meningkatkan Budaya Inovatif: Dengan Peran Mediasi Knowledge Sharing Climate (Studi Pada Dosen Perguruan Tinggi Swasta Di Wilayah Kopertis V Diy)." Jurnal Bisnis: Teori Dan Implementasi 9(1): 13-21. 
International Journal of Economics, Business and Accounting Research (IJEBAR)

Peer Reviewed - International Journal

Vol-3, Issue-4, 2019 (IJEBAR)

E-ISSN: 2614-1280 P-ISSN 2622-4771

https://jurnal.stie-aas.ac.id/index.php/IJEBAR

Press, U. (2016). Membangun Jiwa Entrepreneurship, Universitas Brawijaya Press.

Sari, S. R. (2017). "Organizational Ambidexterity: Ketangguhan Yang Dibutuhkan Untuk Keberlangsungan Kinerja Organisasi Masa Depan." Jurnal Riset Manajemen Dan Bisnis (JRMB) Fakultas Ekonomi UNIAT 2(3): 433-438.

Situmorang, B. (2014). "Pengaruh Perilaku Inovatif Dan Kepemimpinan Pembelajaran Terhadap Kepuasan Kerja Kepala Smp Di Medan." Elementary School Journal 1(2): 26-41.

Suparti, W. (2013). "Implementasi Trilogi Ki Hajar Dewantara Dalam Kepemimpinan Kepala Sekolah Di Sma Taman Madya Ibu Pawiyatan Yogyakarta." Yogyakarta: UIN Sunan Kalijaga.

Supriyanto, A. S. And M. Machfudz (2010). Metodologi Riset Manajemen Sumberdaya Manusia. Malang, UIN MALIKI PRESS.

Suryana, Y. And K. Bayu (2012). Kewirausahaan: Pendekatan Karakteristik Wirausahawan Sukses Ed. 2, Kencana.

Umar, H. (2004). "Riset Sumber Daya Manusia, PT." Gramedia Pustaka Utama \& Jakarta Business Research Center, Jakarta.

Uslu, T., Et Al. (2015). "An Investigation Of The Effects Of Open Leadership To Organizational Innovativeness And Corporate Entrepreneurship." Procedia-Social And Behavioral Sciences 195: 1166-1175.

Wang, C. L. And M. Rafiq (2014). "Ambidextrous Organizational Culture, Contextual Ambidexterity And New Product Innovation: A Comparative Study Of UK And C Hinese High-Tech Firms." British Journal Of Management 25(1): 58-76. 